\title{
Performance of diesel particulate filter catalysts in the presence of biodiesel ash species
}

\author{
Hansen, Brian Brun; Jensen, Anker Degn; Jensen, Peter Arendt
}

Published in:

Fuel

Link to article, DOI:

10.1016/j.fuel.2012.11.038

Publication date:

2013

Document Version

Publisher's PDF, also known as Version of record

Link back to DTU Orbit

\section{Citation (APA):}

Hansen, B. B., Jensen, A. D., \& Jensen, P. A. (2013). Performance of diesel particulate filter catalysts in the presence of biodiesel ash species. Fuel, 106(April), 234-240. https://doi.org/10.1016/j.fuel.2012.11.038

\section{General rights}

Copyright and moral rights for the publications made accessible in the public portal are retained by the authors and/or other copyright owners and it is a condition of accessing publications that users recognise and abide by the legal requirements associated with these rights.

- Users may download and print one copy of any publication from the public portal for the purpose of private study or research.

- You may not further distribute the material or use it for any profit-making activity or commercial gain

- You may freely distribute the URL identifying the publication in the public portal 


\title{
Performance of diesel particulate filter catalysts in the presence of biodiesel ash species
}

\author{
Brian Brun Hansen*, Anker Degn Jensen, Peter Arendt Jensen \\ Department of Chemical and Biochemical Engineering, Technical University of Denmark, Building 229, DK-2800 Kgs. Lyngby, Denmark
}

\section{H I G H L I G H T S}

- Interaction of diesel particulate filter catalysts and biodiesel ash species.

- Catalytic conversion of soot in diesel particulate filters.

- Commercial catalyst (5:1 wt. ratio) decreased soot oxidation temperature.

- Biodiesel ash species $\left(\mathrm{Na}_{2} \mathrm{CO}_{3}, \mathrm{~K}_{2} \mathrm{CO}_{3}\right.$ or $\left.\mathrm{K}_{3} \mathrm{PO}_{4}\right)$ further decreased soot oxidation temperature.

- Engine oil ash species $\left(\mathrm{CaSO}_{4}, \mathrm{Ca}\left(\mathrm{H}_{2} \mathrm{PO}_{4}\right)_{2}\right.$ and $\left.\mathrm{K}_{2} \mathrm{SO}_{4}\right)$ increased soot oxidation temperature.

\section{A R T I C L E I N F O}

\section{Article history:}

Received 16 November 2011

Received in revised form 11 November 2012

Accepted 12 November 2012

Available online 27 November 2012

\section{Keywords:}

DPF

Catalytic filter

Biodiesel

Regeneration

Catalyst activity

\begin{abstract}
A B S T R A C T
The utilization of bio-fuels, such as biodiesel, is expected to contribute significantly towards the planned $10 \%$ of renewable energy within the EU transport sector by 2020. Increased biodiesel blend percentages may change engine exit flue gas ash composition and affect the long-term performance of cleaning technologies, such as oxidation catalysts and diesel particulate filters. In this work the performance of a commercial catalyst has been studied for conversion of diesel particulate matter (SRM 2975) at $10 \% \mathrm{O}_{2}$, in the presence of salts simulating ash species derived from engine oil and biodiesel. Simultaneous thermal analysis experiments of the diesel particulate matter showed that it was dominated by soot with approximately $10 \mathrm{wt}$ \% condensed hydrocarbons. The presence of a commercial catalyst (5:1 wt. ratio of catalyst to soot), in tight contact with the diesel particulate matter, decreased the temperature at which the oxidation rate peaked from $662 \pm 1^{\circ} \mathrm{C}$ to $526 \pm 19^{\circ} \mathrm{C}$. The introduction of biodiesel ash species such as $\mathrm{Na}_{2} \mathrm{CO}_{3}, \mathrm{~K}_{2} \mathrm{CO}_{3}$ or $\mathrm{K}_{3} \mathrm{PO}_{4}$ decreased the peak conversion temperature further $(422 \pm 12 ; 404 \pm 4$ and $423 \pm 7^{\circ} \mathrm{C}$ ), with a limited dependence on ash concentration. A deterioration in catalytic conversion, i.e. increased peak conversion temperatures, was seen for two engine oil ash species and one mixed ash species (from engine oil and biodiesel) $-\mathrm{CaSO}_{4}\left(569 \pm 6{ }^{\circ} \mathrm{C}\right), \mathrm{Ca}\left(\mathrm{H}_{2} \mathrm{PO}_{4}\right)_{2}\left(699 \pm 13{ }^{\circ} \mathrm{C}\right.$ ) and $\mathrm{K}_{2} \mathrm{SO}_{4}$ $\left(581 \pm 16^{\circ} \mathrm{C}\right)$.

Kinetic parameters $\left(A\right.$ and $E_{a}$ ), obtained from Arrhenius plots of the data, showed a lower activation energy in the presence of the commercial catalyst $\left(E_{a}=91 \pm 5 \mathrm{~kJ} / \mathrm{mol}\right)$ or $\mathrm{CeO}_{2}\left(E_{a}=62 \pm 8 \mathrm{~kJ} / \mathrm{mol}\right) \mathrm{com}-$ pared to pure SRM $2975\left(E_{a}=220 \pm 3 \mathrm{~kJ} / \mathrm{mol}\right)$. The obtained kinetic data were able to describe the peak conversion temperature and the associated part of the mass loss curve, but an initial low-temperature gradual increase in conversion was not adequately described.
\end{abstract}

(c) 2012 Elsevier Ltd. All rights reserved.

\section{Introduction}

Emissions from the transport sector and its contribution to global warming and detrimental effects on human health have become focus of growing concerns and awareness in recent years. This has caused the EU to aim for $10 \%$ renewable energy in the transport sector and $20 \%$ renewable energy overall by 2020 [1]. The introduction of bio-fuels (ethanol, biodiesel, etc.) into the transport sector is ex-

\footnotetext{
* Corresponding author. Tel.: +45 45252829; fax: +45 45882258.

E-mail address: bbh@kt.dtu.dk (B.B. Hansen).
}

pected to contribute significantly to these goals. The introduction of new fuels or changes in fuel properties may affect engine performance, emissions, ash composition and long-term interactions with cleaning technologies such as the oxidation catalyst (DOC), the diesel particulate filter (DPF) and selective catalytic reduction of $\mathrm{NO}_{x}$ (SCR) [2]. Even a low concentration of catalyst poison in the exhaust may severely affect the performance of cleaning technologies as seen for power plants burning biomass [3-5].

Previous engine emission improvements were obtained by stricter fuel specifications and engine optimization, while after treatment systems, such as DPF and SCR, will likely be necessary 


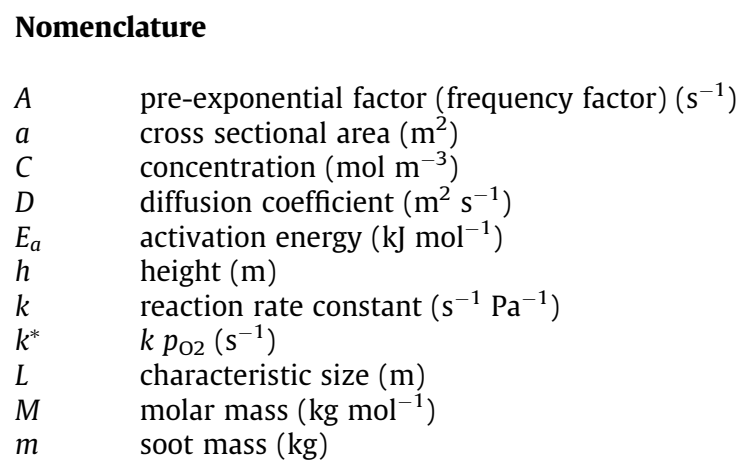

$\begin{array}{ll}p & \text { partial pressure }(\mathrm{Pa}) \\ R & \text { universal gas constant }\left(\mathrm{m}^{3} \mathrm{~Pa} \mathrm{~K}^{-1} \mathrm{~mol}^{-1}\right) \\ \rho & \text { density }\left[\mathrm{kg} \mathrm{m}^{-3}\right] \\ t & \text { time }(\mathrm{s}) \\ T & \text { temperature }\left({ }^{\circ} \mathrm{C}\right) \\ & \\ \text { Subscript } & \\ b & \text { bulk phase } \\ e & \text { effective } \\ \text { obs } & \text { observed } \\ \text { peak } & \text { peak in mass loss rate }\end{array}$

to comply with the latest US and European legislation [6]. In the case of particulate emissions, a flow through DOC is capable of oxidising CO and gaseous hydrocarbons, that otherwise could condense and contribute to particle formation. The highly efficient DPF traps 95-99\% PM by forcing the exhaust through a porous wall, thereby initially capturing PM in the pores followed by cake filtration on top of the channel walls $[7,8]$. To avoid excessive backpressure periodically DPF cleaning/regeneration by soot oxidation into $\mathrm{CO}_{2}$ (reaction with $\mathrm{O}_{2}$ or $\mathrm{NO}_{2}$ ) is necessary. Two different regeneration strategies may be employed: Active regeneration at $500-800{ }^{\circ} \mathrm{C}$ (temperature increased by fuel injection) or passive regeneration down to $250-300{ }^{\circ} \mathrm{C}$ by either a catalytic fuel additive, a catalytic DPF coating for soot conversion or catalytic conversion of $\mathrm{NO}$ to $\mathrm{NO}_{2}$ and subsequent low temperature soot oxidation by $\mathrm{NO}_{2}[6,9]$. Most modern system use noble metal based DOC and DPF formulations for indirect soot oxidation (through $\mathrm{NO}_{2}$ formation), but direct catalytic soot oxidation by $\mathrm{O}_{2}$ is expected to become increasingly important for future catalytic DPF's due to an increased focus on lower engine out $\mathrm{NO}_{x}$ (emission standards) and fuel economy (benefits from swifter and more frequent filter regeneration) [10,11]. A swift, cheap and energy efficient filter regeneration is desired, while maintaining filter integrity (no thermal run away or steep temperature gradients). Understanding the kinetics of filter regeneration is consequently of importance for filter optimization and regeneration strategies. The ash (incombustible residue) generated from engine oil, fuel, additives and engine/ exhaust wear will accumulate in the DPF and eventually constitute the majority of trapped material. This influences catalytic DPF baseline pressure drop, pressure drop sensitivity and potentially affect regeneration frequency, heat release and performance $[6,7,12]$. The ash composition and properties will depend on fuel/ oil origin, additives, DPF temperature history, etc. and the introduction of new fuels, such as bio-fuels, may change these.

The introduction of biodiesel has been reported to cause an increased reactivity of particulate matter $[13,14]$ and some changes in ash composition $[6,15]$. The increased reactivity has been attributed to a more open structure of the de-volatilized biodiesel PM, allowing swifter $\mathrm{O}_{2}$ diffusion to reactive sites, which is supported by the extraction of overall ultra low sulphur diesel (ULSD)/ pure biodiesel (B100) kinetic data when normalising with the instantaneous surface area $\left(E_{a}=113 \mathrm{~kJ} / \mathrm{mol}\right)$ [14]. Reported ash compositions from experiments with pure ULSD are dominated by species from the engine oil ( $\sim 90 \%$ : Ca, Mg, Zn, P, S, B, Mo) in the form of: calcium sulphate, zinc phosphate, magnesium phosphate, magnesium sulphate and calcium phosphate [6,8,12]. Minor amounts of engine/exhaust wear components ( $\mathrm{Al}, \mathrm{Co}, \mathrm{Cr}, \mathrm{Cu}, \mathrm{Fe}$, $\mathrm{Mn}, \mathrm{Ni}, \mathrm{Pb}, \mathrm{Si}, \mathrm{Sn}, \mathrm{Ti}, \mathrm{V}$ ), primarily as $\mathrm{Fe}_{3} \mathrm{O}_{4}$, are also present [6]. The utilisation of a $20 \%$ soybean methyl ester blend yielded ash similar in composition, except a somewhat higher content of en- gine/exhaust wear elements ( $\sim 16 \mathrm{wt} . \%)$ and fuel alkali ( $\sim 6 \mathrm{wt} . \%$ $\mathrm{Na}$ and $\mathrm{K}$ ) [6]. This is supported by the presence of biodiesel alkali elements ( $4.2 \mathrm{wt} . \% \mathrm{Na}$ and $2.1 \mathrm{wt} . \% \mathrm{~K}$ ) in a survey of the particulate matter (ash + soot) collected after pneumatic cleaning of DPF/DOC on US vehicles [15]. The introduction of biodiesel may generally contribute with the elements $\mathrm{Na}, \mathrm{K}, \mathrm{Ca}, \mathrm{Mg}$ and $\mathrm{P}$, but the concentration of these elements is limited by standards such as the European EN14214 standard ( $\mathrm{Na}+\mathrm{K} \leqslant 5 \mathrm{mg} / \mathrm{kg}, \mathrm{Ca}+\mathrm{Mg} \leqslant 5 \mathrm{mg} / \mathrm{kg}$ and $\mathrm{P} \leqslant 4 \mathrm{mg} / \mathrm{kg}$ ). The ash obtained from experiments with an off-spec $100 \%$ canola methyl ester ( $\mathrm{Na}+\mathrm{K}$ and $\mathrm{Ca}+\mathrm{Mg}$ exceeded specifications 10 times) yielded a significantly changed ash composition consisting of: calcium oxide, magnesium oxide, sodium phosphate, calcium phosphate and magnesium phosphate with $37 \mathrm{wt} . \%$. $\mathrm{Na}+\mathrm{K}[6]$.

Several studies of carbon oxidation (carbon black as well as automotive PM containing both soot and adsorbed hydrocarbons) and screening studies of various catalyst for soot/hydrocarbon conversion have been published in the literature $[9,16-18]$ as has a few studies on the interaction between ash and DPF/after treatment systems [7-8,12,19]. Bardasz et al. [12] studied the influence of engine oil composition and ash content on continuously regenerating DPF, DOC and SCR performance on a $230 \mathrm{~kW}$ Euro IV prototype engine for simulated driving distance upto $115,000 \mathrm{~km}$. No significant changes in DPF or DOC catalytic activity were found. Doping high ash oil into the fuel, a practice used for disposal or accelerated tests, did however cause rapid increases in DPF backpressure, changes in ash distribution and an increased ash density within the DPF. Sappok and Wong [7] studied the effect of ash on pressure drop and regeneration frequency by accelerated ash loading test with a $224 \mathrm{~kW}$ Cummins ISB engine. Ash was observed to accumulate and form end plugs in the inflow channels, thereby decreasing the effective filter volume, increasing pressure drop and causing changes in local soot concentration.

The aim of this work is to extend the present knowledge on the interaction between automotive ash species (especially from biodiesel) and catalytic DPF's in $10 \% \mathrm{O}_{2}$ by simulated filter regeneration experiments in lab-scale using simultaneous thermal analysis. This entails a detailed characterisation of non-catalytic and catalytic soot combustion in the presence of salts simulating different ash compositions. Direct catalytic soot oxidation by $\mathrm{O}_{2}$ will likely become increasingly important for future catalytic DPF's due to focus on lower engine out $\mathrm{NO}_{x}$ (emission standards) and fuel economy (benefits from swifter and more frequent filter regeneration) [10].

\section{Strategy of investigation}

This investigation of soot reactivity, oxidation behaviour and the influence of catalytic materials and various salts (simulated 
Table 1

Overview of performed experiments.

\begin{tabular}{|c|c|c|c|c|c|c|c|}
\hline Experiment & Heating rate $\left({ }^{\circ} \mathrm{C} \min ^{-1}\right)$ & $\mathrm{O}_{2}$ vol \% & Carbon & Catalyst & Salt & Wt. ratio ${ }^{a}$ & $T_{\text {peak }}\left({ }^{\circ} \mathrm{C}\right)$ \\
\hline $1-2$ & 10 & 10 & SRM 2975 & - & - & $1: 0: 0$ & $662 \pm 1$ \\
\hline $3-4$ & 10 & 10 & Sigma & - & - & $1: 0: 0$ & $723 \pm 1$ \\
\hline $5-10$ & 10 & 10 & SRM 2975 & Commercial & - & $1: 5: 0$ & $526 \pm 19$ \\
\hline $11-12$ & 10 & 10 & Sigma & Commercial & - & $1: 5: 0$ & $571 \pm 16$ \\
\hline $13-15$ & 10 & 10 & SRM 2975 & $\mathrm{CeO}_{2}$ & - & $1: 5: 0$ & $442 \pm 8$ \\
\hline $16-17$ & 10 & 10 & SRM 2975 & $\mathrm{TiO}_{2}$ & - & $1: 5: 0$ & $648 \pm 6$ \\
\hline $18-19$ & 10 & 10 & SRM 2975 & Commercial & - & $1: 10: 0$ & $480 \pm 10$ \\
\hline 20 & 10 & 10 & SRM 2975 & Commercial & - & $1: 20: 0$ & 497 \\
\hline $21-22$ & 10 & 10 & SRM 2975 & Commercial & $\mathrm{CaCl}_{2}$ & $1: 5: 2.5$ & $506 \pm 1$ \\
\hline $23-24$ & 10 & 10 & SRM 2975 & Commercial & $\mathrm{CaSO}_{4}$ & $1: 5: 2.5$ & $569 \pm 6$ \\
\hline $25-29$ & 10 & 10 & SRM 2975 & Commercial & $\mathrm{Ca}\left(\mathrm{H}_{2} \mathrm{PO}_{4}\right)_{2}$ & $1: 5: 2.5$ & $699 \pm 13$ \\
\hline $30-31$ & 10 & 10 & SRM 2975 & Commercial & $\mathrm{CaCO}_{3}$ & $1: 5: 2.5$ & $554 \pm 4$ \\
\hline 32 & 10 & 10 & SRM 2975 & Commercial & $\mathrm{KCl}$ & $1: 5: 2.5$ & 520 \\
\hline $33-34$ & 10 & 10 & SRM 2975 & Commercial & $\mathrm{K}_{2} \mathrm{SO}_{4}$ & $1: 5: 2.5$ & $581 \pm 16$ \\
\hline $35-37$ & 10 & 10 & SRM 2975 & Commercial & $\mathrm{K}_{3} \mathrm{PO}_{4}$ & $1: 5: 2.5$ & $423 \pm 7$ \\
\hline $38-39$ & 10 & 10 & SRM 2975 & Commercial & $\mathrm{K}_{2} \mathrm{CO}_{3}$ & $1: 5: 0.5$ & $425 \pm 8$ \\
\hline $40-41$ & 10 & 10 & SRM 2975 & Commercial & $\mathrm{K}_{2} \mathrm{CO}_{3}$ & $1: 5: 1.5$ & $413 \pm 4$ \\
\hline $42-43$ & 10 & 10 & SRM 2975 & Commercial & $\mathrm{K}_{2} \mathrm{CO}_{3}$ & $1: 5: 2.5$ & $404 \pm 4$ \\
\hline $44-45$ & 10 & 10 & SRM 2975 & Commercial & $\mathrm{NaCl}$ & $1: 5: 2.5$ & $527 \pm 7$ \\
\hline $46-47$ & 10 & 10 & SRM 2975 & Commercial & $\mathrm{Na}_{2} \mathrm{SO}_{4}$ & $1: 5: 2.5$ & $537 \pm 12$ \\
\hline $48-49$ & 10 & 10 & SRM 2975 & Commercial & $\mathrm{Na}_{2} \mathrm{HPO}_{4}$ & $1: 5: 2.5$ & $528 \pm 20$ \\
\hline 50 & 10 & 10 & SRM 2975 & Commercial & $\mathrm{Na}_{2} \mathrm{CO}_{3}$ & $1: 5: 0.5$ & 451 \\
\hline 51 & 10 & 10 & SRM 2975 & Commercial & $\mathrm{Na}_{2} \mathrm{CO}_{3}$ & $1: 5: 1.5$ & 434 \\
\hline $52-53$ & 10 & 10 & SRM 2975 & Commercial & $\mathrm{Na}_{2} \mathrm{CO}_{3}$ & $1: 5: 2.5$ & $422 \pm 10$ \\
\hline $54-55$ & 10 & 10 & SRM 2975 & Commercial & $\mathrm{Zn}\left(\mathrm{CH}_{3} \mathrm{COO}\right)_{2}$ & $1: 5: 2.5$ & $467 \pm 5$ \\
\hline $56-57$ & 10 & 0 & SRM 2975 & - & - & 1:0:0 & - \\
\hline $58-60$ & 5 & 10 & SRM 2975 & - & - & $1: 0: 0$ & $643 \pm 2$ \\
\hline $61-62$ & 5 & 10 & SRM 2975 & Commercial & - & $1: 5: 0$ & $515 \pm 1$ \\
\hline 63 & 10 & 20 & SRM 2975 & Commercial & - & $1: 5: 0$ & 520 \\
\hline
\end{tabular}

a Mass carbon/mass carbon: mass catalyst/mass carbon: mass salt (cation only)/ mass carbon.

ash species) have been performed by ex situ studies in a Simultaneous Thermal Analyzer (Netzsch STA 449 F1 Jupiter) combining thermo gravimetric analysis (TGA) and differential scanning calorimetry (DSC). This apparatus offers a simple and versatile performance combined with well-controlled experimental conditions [13]. The experiments performed, shown in Table 1, investigate the reactivity of mixtures of diesel PM, catalysts and various salts/simulated ash species (carbonates, phosphates and sulphates). Chloride salts have furthermore been included due to their lower melting points and thereby potential for a higher mobility and tighter diesel PM/catalyst contact. The effects of heating rates and $\mathrm{O}_{2}$ concentration have furthermore been investigated for selected samples. The reactivity of the mixtures will be evaluated based on the temperature at which the maximal conversion rate takes place and kinetic data will be extracted based on Arrhenius plots.

\section{Experimental setup and procedure}

\subsection{Procedure}

The mixtures described in Table 1 were prepared by: Mixing the catalytic powder and the dissolved salt, drying at $50{ }^{\circ} \mathrm{C}$, diesel PM/ carbon addition and grinding in a mortar for $5 \mathrm{~min}$ and finally addition of a few drops of ethanol to further benefit diesel PM/ carbon-catalyst interaction as it evaporates. This procedure was used to obtain the close diesel PM/carbon-catalyst interaction needed for studies of catalytic effects [17]. Early DPF monolith studies of catalyst-soot contact at real world conditions indicated a limited interaction and conversion rates close to pure soot (except for more mobile catalysts) [20], but recent studies have shown contributions from both thermal soot conversion and catalytic promoted soot conversion - especially for advanced DPF coatings that have been shown to promote soot/catalyst proximity [10]. The generated mixture was then transferred to an alumina crucible and heated to $750{ }^{\circ} \mathrm{C}$ in the STA (heating ramp $5-10^{\circ} \mathrm{C} / \mathrm{min}$ ) at a gas flow of
$100 \mathrm{ml} / \mathrm{min}$. The $\mathrm{O}_{2}$ concentration (10\%) was chosen within the typical range of diesel exhausts (5-15\%) [17], but selected samples were also tested at $0 \%$ and $20 \% \mathrm{O}_{2}$. No pre-treatment of diesel $\mathrm{PM} /$ carbon in an inert atmosphere was carried out, as this would potentially remove the condensed hydrocarbons (a relevant part of automotive PM) and alter the available surface area [17].

\subsection{Chemicals}

A standard reference material from NIST (SRM 2975 - diesel particulate matter from fork lifts) was used as automotive particulate matter/diesel soot, but a carbon nanopowder (Sigma-Aldrich $>99.95 \%$ ) was also used for selected samples. The main part of this study is performed with a commercial catalyst supplied by Dinex A/S ( $\sim 2 \% \mathrm{Pt}, \sim 20 \% \mathrm{CeO}_{2}$ and $\sim 78 \% \mathrm{TiO}_{2}$ ), but experiments with $\mathrm{CeO}_{2}$ (Sigma-Aldrich) and $\mathrm{TiO}_{2}$ (Riede-de Haen 99\%) have also been performed to verify the active species and to test for a "dilution effect" by inert materials. The salts used were of analytical grade unless otherwise stated: $\mathrm{CaCl}_{2} \cdot 2 \mathrm{H}_{2} \mathrm{O}$ (Brenntag Nordic), $\mathrm{CaSO}_{4} \cdot 2 \mathrm{H}_{2} \mathrm{O}$ (Sigma), $\mathrm{Ca}\left(\mathrm{H}_{2} \mathrm{PO}_{4}\right)_{2}$ (Aldrich - technical grade), $\mathrm{CaCO}_{3}$ (J.T. Baker), $\mathrm{KCl}$ (Fluka), $\mathrm{K}_{2} \mathrm{SO}_{4}$ (Merck), $\mathrm{K}_{3} \mathrm{PO}_{4}$ (Sigma), $\mathrm{K}_{2} \mathrm{CO}_{3}$ (Merck), $\mathrm{NaCl}$ (Merck), $\mathrm{Na}_{2} \mathrm{SO}_{4}$ (Riedel-de Haen), $\mathrm{Na}_{2} \mathrm{HPO}_{4} \cdot 7 \mathrm{H}_{2} \mathrm{O}$ (Merck), $\mathrm{Na}_{2} \mathrm{CO}_{3}$ (Merck) and $\mathrm{ZnC}_{4} \mathrm{H}_{6} \mathrm{O}_{4}-2 \mathrm{H}_{2} \mathrm{O}$ (Fluka).

\section{Estimation of characteristic oxidations temperatures and kinetic parameters}

The development in sample mass as a function of temperature and time can be used for studies of characteristic oxidation temperatures as well as extraction of kinetic parameters [13]. A running average (upto 200 data points, corresponding to $15^{\circ} \mathrm{C}$ ) was used to reduce signal noise and improve data interpretation, after it was verified that no data distortion occurred. Mixtures of diesel $\mathrm{PM} /$ carbon, catalyst and salt exhibit several different changes in mass during one run due to water evaporation, decomposition of the salt and soot combustion. In order to distinguish the different 
processes taking place in these experiments, runs with pure salts were performed and the DSC signal of the mixtures was furthermore used to identify the soot combustion segment. This work will mainly focus on the temperature at which the maximum mass loss rate takes place, but other additional characteristic temperatures (ignition/starting oxidation temperature, final oxidation temperature, etc.) have also been used in the literature $[9,13,16]$.

An Arrhenius type equation, Eq. (1), has been used to extract the kinetic data used to simulate the soot oxidation in a $10 \% \mathrm{O}_{2}$ atmosphere without water. A first order reaction with respect to soot and oxygen should be appropriate at the low temperature regime used in this study $[13,16]$.

$\frac{d m}{d t}=k \cdot m \cdot p_{\mathrm{O}_{2}}=k^{*} \cdot m \cdot=A \cdot \exp \left(-E_{a} / R T\right) \cdot m$

$\rightarrow \ln \left(-\frac{d m}{m \cdot d t}\right)=\ln (A)-\frac{E_{a}}{R \cdot T}$

where $m$ is the actual soot mass, $t$ is the time, $k$ is the reaction rate constant, $A$ is a pre-exponential factor (frequency factor), $E_{a}$ is the activation energy and $p_{\mathrm{O} 2}$ is the partial pressure of oxygen. For some purposes the reaction rate constant may furthermore be split into two terms: a total number of active sites and a temperature dependent reaction rate constant [17]. Rearranging Eq. (1) yields the well known form used for an Arrhenius plot, from which the pre-exponential factor (from the $y$-axis intercept) and the activation energy (from the slope) can be extracted. Experimentally estimated values of the frequency factor are, however, affected by severe errors due to high sensitivity of the $y$-axis intercept on small variations of the slope [21]. Only the central linear part of mass vs. temperature TG curve was used to extract kinetic data in this study. This was only done for pure diesel PM/carbon samples and carbon/catalyst mixtures, because the carbon wt.\% of carbon-catalyst-salt mixtures became too low to obtain reasonable estimates for a linear Arrhenius plot. Extracted kinetic parameters may furthermore be dependent on flow rate, heating ramp, sample mass or be partially controlled by diffusion $[13,16,17]$. The following equations have been used to check whether the effects of oxygen diffusion into the $5 \%$ filled crucible (Eq. (2)) or the oxygen diffusion into the carbon layer relative to the maximal kinetic consumption rate (Eq. (3), Mw (Wagner-Weisz-Wheeler modulus)) are significant $[16,22]$.

$k_{o b s} \cdot \frac{m}{M_{C}}<\frac{D_{\mathrm{O}_{2}}}{0.95 \cdot h} \cdot a \cdot C_{\mathrm{O}_{2}, b}$

$M w=L^{2} \cdot\left(\frac{\frac{d m}{d t} / M_{c} \cdot\left(\frac{\rho}{m}\right)}{C_{\mathrm{O}_{2}}}\right) / D_{e, \mathrm{O}_{2}}<0.15$

where $k_{o b s}$ is the rate constant observed $\left(0.003 \mathrm{~s}^{-1}\right)$ at maximal mass loss rate $\left(d m / d t=2 \cdot 10^{-9} \mathrm{~kg} \mathrm{~s}^{-1}\right), m$ the carbon/soot mass $\left(0.7 \cdot 10^{-6} \mathrm{~kg}\right), M$ the molar mass $\left(0.012 \mathrm{~kg} \mathrm{~mol}^{-1}(\mathrm{C})\right), D$ the diffusion coefficient $\left(10^{-4} \mathrm{~m}^{2} \mathrm{~s}^{-1}\right.$ in the gas layer and $10^{-5} \mathrm{~m}^{2} \mathrm{~s}^{-1}$ in the soot layer), $h$ the crucible height $\left(3 \cdot 10^{-3} \mathrm{~m}\right), a$ the cross sectional area $\left(3 \cdot 10^{-5} \mathrm{~m}^{2}\right), C_{O_{2}, b}$ the oxygen concentration outside the crucible $\left(1.3 \mathrm{~mol} \mathrm{~m}^{-3}\right), L$ a characteristic size (0.05.h for a $5 \%$ filled crucible), $\rho$ the particle bed density $\left(150 \mathrm{~kg} \mathrm{~m}^{-3}\right)$. By inserting these approximate values it can be shown, that oxygen diffusion from the crucible top to the carbon layer will in the worst case be 8 times greater than the consumption (in most cases much higher) and that oxygen will fully penetrate the carbon layer $\left(\mathrm{M}_{\mathrm{w}}=0.06<0.15\right)$.

\section{Results and discussion}

The experimental work includes experiments with pure diesel particulate matter as well as mixtures of carbon, catalytic material and salts simulating biodiesel ash species. Different mixture ratios, gas composition and heating rates have furthermore been investigated. Details of the experiments are given in Table 1.

Fig. 1 shows the development in mass and mass loss rate for pure SRM 2975 particulate matter samples in both pure nitrogen and $10 \% \mathrm{O}_{2}$, and at heating rates of 5 and $10^{\circ} \mathrm{C} / \mathrm{min}$. Fig. 2 compares the mass and mass loss rate for SRM 2975 and Sigma "carbon nanopowder". The pure SRM 2975 show a gradual decline in mass from approximately $200{ }^{\circ} \mathrm{C}$ in both $100 \% \mathrm{~N}_{2}$ and $10 \% \mathrm{O}_{2}$. This is likely due to evaporation of condensed hydrocarbons or adsorbed sulphates [16], a hypothesis which is supported by the constant mass of the Sigma "carbon nanopowder" at these temperatures. At higher temperatures $\left(\sim 550-600^{\circ} \mathrm{C}\right)$ combustion begins to take place in $10 \% \mathrm{O}_{2}$, somewhat later for the Sigma "carbon nanopowder" than for the SRM 2975. Such differences in the oxidation behaviour of carbon and soot samples may originate from differences in size, structure or composition [17]. The obtained peak conversion temperature for SRM 2975 at $10 \mathrm{k} / \mathrm{min}\left(662 \pm 1{ }^{\circ} \mathrm{C}\right)$ is similar to values reported for other soot STA experiments $\left(655^{\circ} \mathrm{C}\right)[9]$ but it is somewhat higher than what has been reported for devolatilised diesel PM $\left(\sim 550^{\circ} \mathrm{C}\right)$ [13]. A decreased heating rate shifted the start of combustion and the peak in conversion rate towards lower temperatures, with reasonable repeatability for both heating rates $-5^{\circ} \mathrm{C} / \mathrm{min}$ ( 3 experiments) and $10^{\circ} \mathrm{C} / \mathrm{min}$ (2 experiments). Due to the faster processing time $10^{\circ} \mathrm{C} / \mathrm{min}$ was chosen for the subsequent samples.

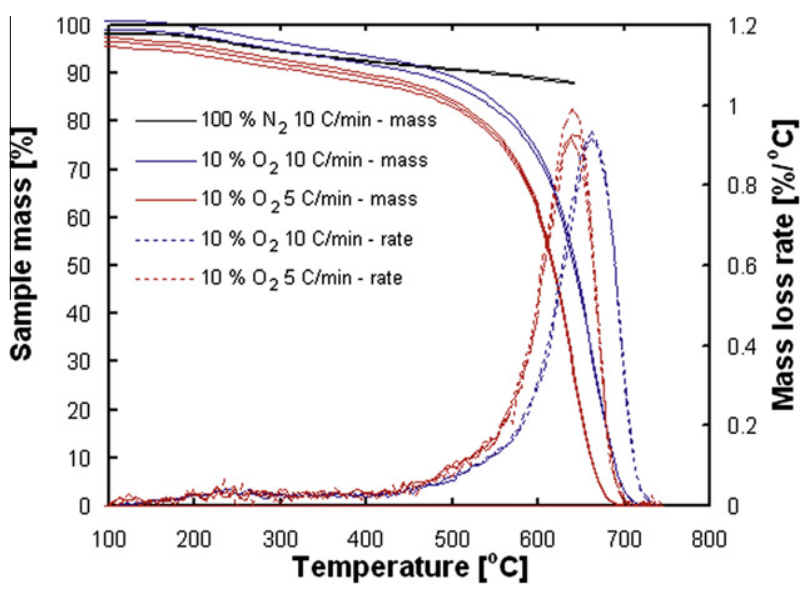

Fig. 1. Influence of heating rate and gas phase composition on the mass and mass loss rate of SRM 2975.

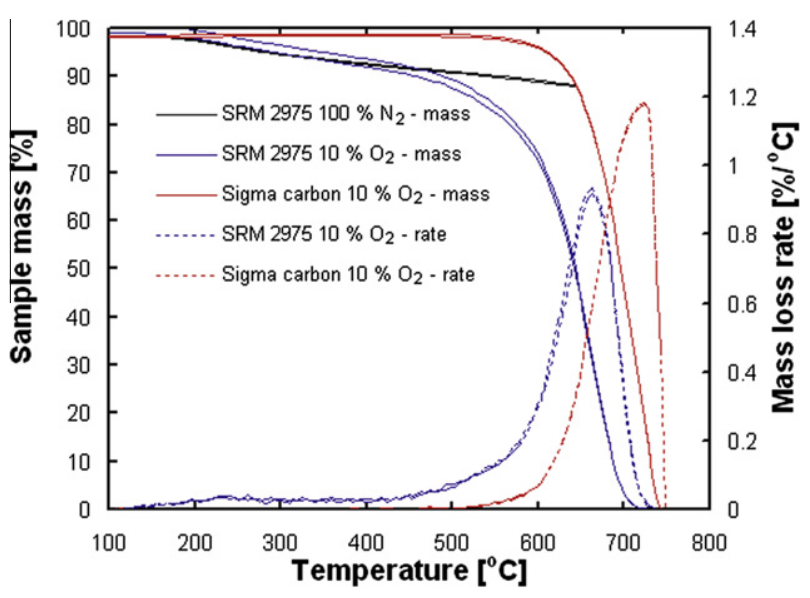

Fig. 2. Mass and mass loss rate of different carbon samples. 
Fig. 3 shows the mass and mass loss rate for 5:1 mixtures of catalytic material (Commercial catalyst, $\mathrm{CeO}_{2}$ and $\mathrm{TiO}_{2}$ ) and SRM 2975. The final mass obtained correspond to the wt.\% catalyst in the mixture. This property shows some variation, likely due to the elusive nature of diesel PM/carbon during the grinding and transfer parts of the sample preparation procedure. The samples with higher residual mass and thereby a higher catalyst fraction also resulted in higher reactivities - i.e. peak in mass loss rate at

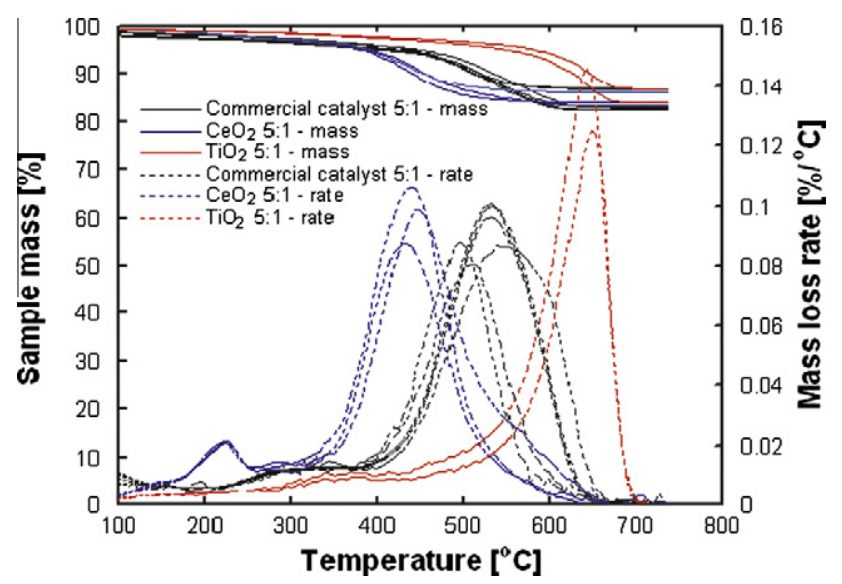

Fig. 3. Mass and mass loss rate of $5: 1$ catalyst/SRM 2975 mixtures $\left(10 \% \mathrm{O}_{2}\right.$ at $10{ }^{\circ} \mathrm{C} /$ $\min )$.

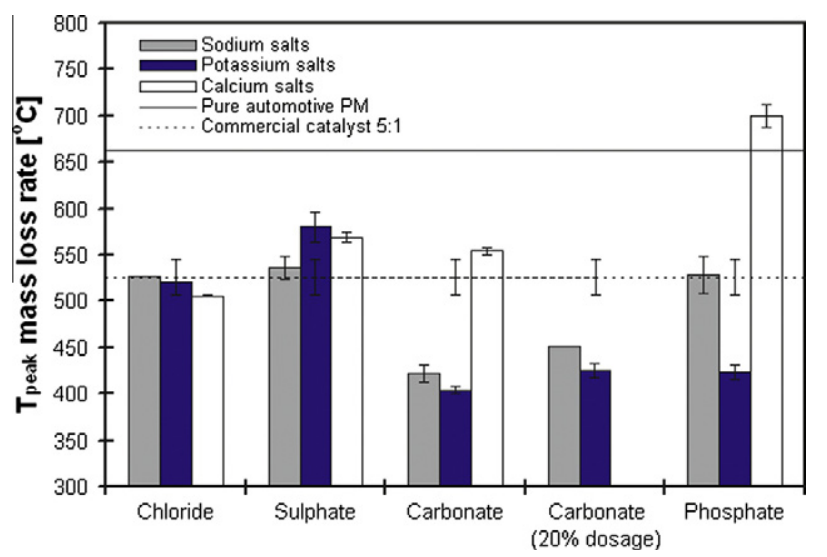

Fig. 4. Temperature of maximal mass loss rate for carbon/catalyst/salt mixtures $\left(10 \% \mathrm{O}_{2}\right.$ at $\left.10^{\circ} \mathrm{C} / \mathrm{min}\right)$. Error bars indicate standard deviation. The solid and the dashed line illustrate the temperature at which mass loss rate peaked for pure SRM 2975 and a 5:1 mixture with the commercial catalyst respectively. a lower temperature. The presence of a commercial catalyst decreased the peak conversion temperature (from $662 \pm 1$ to $526 \pm 19^{\circ} \mathrm{C}$ ), a decrease similar to what have been reported elsewhere for other catalytic materials tested on soot $[9,16]$. The lower temperature reported for passive DPF regeneration $\left(250-300{ }^{\circ} \mathrm{C}\right.$ [6]) is likely due to the presence of $\mathrm{NO}_{2}$ in exhaust - but this species could not be introduced to the STA. The samples with $\mathrm{CeO}_{2}$ showed a higher reactivity than samples with commercial catalyst. $\left(\sim 20 \% \mathrm{CeO}_{2}\right)$, while $\mathrm{TiO}_{2}$ samples showed a reactivity similar to pure SRM 2975 and the presence of this compound in the commercial formulation are probably due to other factors such as providing a high surface area.

Fig. 4 compares the temperature at which the mass loss rate peaks for different carbon-catalyst-salt mixtures. The mixtures with chloride salts added showed no significant changes in catalytic conversion behaviour of SRM 2975. A significant beneficial effect of $\mathrm{Na}_{2} \mathrm{CO}_{3}$ and $\mathrm{K}_{2} \mathrm{CO}_{3}$ was seen, as it also has been reported for carbon black/model soot oxidation [17] and gasification of carbonaceous materials [18]. The beneficial effect of $\mathrm{Na}_{2} \mathrm{CO}_{3}$ was also present at an $80 \%$ lower dosage and it did not change/decrease for two subsequent runs with reused $\mathrm{Na}_{2} \mathrm{CO}_{3} /$ commercial catalyst mixtures. The beneficial effect of alkali carbonates are likely due to the formation of active alkali metal oxides and peroxides species [18]. However, $\mathrm{CaCO}_{3}$ increased the peak conversion temperature slightly (from $526 \pm 19^{\circ} \mathrm{C}$ to $554 \pm 4^{\circ} \mathrm{C}$ ). A deterioration was seen for mixtures with $\mathrm{K}_{2} \mathrm{SO}_{4}$ and $\mathrm{CaSO}_{4}\left(581 \pm 16{ }^{\circ} \mathrm{C}\right.$ and $\left.569 \pm 6{ }^{\circ} \mathrm{C}\right)$, while no significant effect could be seen for $\mathrm{Na}_{2} \mathrm{SO}_{4}\left(537 \pm 12^{\circ} \mathrm{C}\right)$. Different phosphorous salts $\left(\mathrm{K}_{3} \mathrm{PO}_{4}, \mathrm{Na}_{2} \mathrm{HPO}_{4}-7 \mathrm{H}_{2} \mathrm{O}\right.$ and $\left.\mathrm{Ca}\left(\mathrm{H}_{2} \mathrm{PO}_{4}\right)_{2}\right)$ were used causing different results. The $\mathrm{K}_{3} \mathrm{PO}_{4}$ caused a significant beneficial effect on catalytic conversion $\left(423 \pm 7{ }^{\circ} \mathrm{C}\right.$ ), while $\mathrm{Na}_{2} \mathrm{HPO}_{4}-7 \mathrm{H}_{2} \mathrm{O}$ and $\mathrm{Ca}\left(\mathrm{H}_{2} \mathrm{PO}_{4}\right)_{2}$ had a negligible $\left(528 \pm 20^{\circ} \mathrm{C}\right)$ and a significantly deteriorating effect $\left(699 \pm 13^{\circ} \mathrm{C}\right)$ respectively. Based on the behaviour of sodium and potassium carbonate, sodium phosphate is expected to have a beneficial effect on soot conversion similar to potassium phosphate. Zinc acetate also benefitted the catalytic conversion $\left(467 \pm 5^{\circ} \mathrm{C}\right)$, but slightly less than sodium and potassium carbonate.

Table 2 shows the kinetic parameters ( $A$ and $E_{a}$ ) obtained from Arrhenius plots of the diesel PM and diesel PM/catalyst mixtures. As reported in the literature estimates of the pre-exponential factor (A) is not well determined due to the high sensitivity towards small variations in the slope of the Arrhenius plot [21]. This is most pronounced for mixtures of carbon and catalyst, because the mass loss only constituted a few percent of the initial sample mass. The obtained activation energy of diesel particulate matter $(220 \pm 3 \mathrm{~kJ} / \mathrm{mol})$ are just above what has been reported in the literature for carbon oxidation (102-210 kJ/mol) [16]. The lower values obtained for diesel PM in the literature $(\sim 110-115 \mathrm{~kJ} / \mathrm{mol}[13,14])$, may be the result of differences in carbon structure and the presence of catalytic metals/ash [16]. The presence of catalytic species

Table 2

Estimated kinetic parameters (standard deviation indicated by \pm ).

\begin{tabular}{|c|c|c|c|c|c|c|c|}
\hline Experiment & Composition carbon/catalyst/salt & Wt. ratio ${ }^{a}$ & Heating rate $\left({ }^{\circ} \mathrm{C} \mathrm{min}^{-1}\right)$ & $\mathrm{O}_{2}$ vol.\% & $T_{\text {peak }}\left({ }^{\circ} \mathrm{C}\right)$ & $A\left(\min ^{-1}\right)$ & $E_{a}\left(\mathrm{~kJ} \mathrm{~mol}{ }^{-1}\right)$ \\
\hline $1-2$ & SRM 2975 & $1: 0: 0$ & 10 & 10 & $662 \pm 1$ & $5.8( \pm 2.0) 10^{11}$ & $220 \pm 3$ \\
\hline $3-4$ & Sigma carbon & $1: 0: 0$ & 10 & 10 & $723 \pm 1$ & $5.5( \pm 1.2) 10^{12}$ & $249 \pm 2$ \\
\hline $5-10$ & SRM 2975/commercial & $1: 5: 0$ & 10 & 10 & $526 \pm 19$ & $2.4( \pm 2.9) 10^{5}$ & $91 \pm 5$ \\
\hline $11-12$ & Sigma/commercial & $1: 5: 0$ & 10 & 10 & $571 \pm 16$ & $1.6( \pm 2.2) 10^{5}$ & $91 \pm 19$ \\
\hline $13-15$ & SRM $2975 / \mathrm{CeO}_{2}$ & $1: 5: 0$ & 10 & 10 & $442 \pm 8$ & $8.6( \pm 10.6) 10^{3}$ & $62 \pm 8$ \\
\hline $16-17$ & SRM $2975 / \mathrm{TiO}_{2}$ & $1: 5: 0$ & 10 & 10 & $648 \pm 6$ & $8.8( \pm 12.1) 10^{14}$ & $258 \pm 25$ \\
\hline $18-19$ & SRM 2975/commercial & $1: 10: 0$ & 10 & 10 & $480 \pm 10$ & $1.0( \pm 1.4) 10^{5}$ & $78 \pm 15$ \\
\hline 20 & SRM 2975/commercial & $1: 20: 0$ & 10 & 10 & 497 & $6.610^{3}$ & 69 \\
\hline $58-60$ & SRM 2975 & $1: 0: 0$ & 5 & 10 & $643 \pm 2$ & $1.6( \pm 1.3) 10^{12}$ & $231 \pm 3$ \\
\hline $61-62$ & SRM 2975/commercial & $1: 5: 0$ & 5 & 10 & $515 \pm 1$ & $9.2( \pm 0.8) 10^{4}$ & $90 \pm 1$ \\
\hline 63 & SRM 2975/commercial & $1: 5: 0$ & 10 & 20 & 520 & $5.610^{5}$ & 98 \\
\hline
\end{tabular}

a Mass carbon/mass carbon: mass catalyst/mass carbon: mass salt (cation only)/mass carbon. 


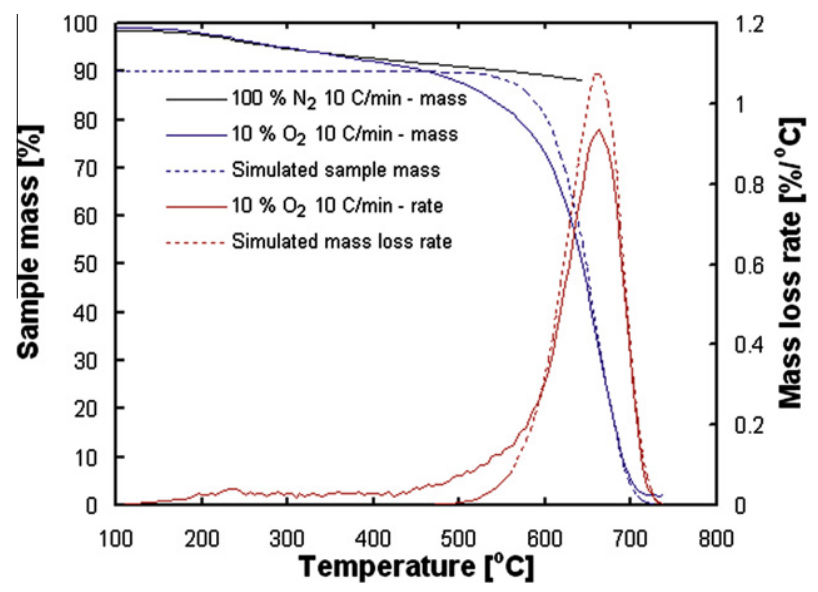

Fig. 5. Measured and simulated sample mass and mass loss rate for $5: 1$ catalyst/ SRM 2975 mixtures.

decreased the activation energy to $62 \pm 8 \mathrm{~kJ} / \mathrm{mol}\left(\mathrm{CeO}_{2}\right)$ and $91 \pm 5 \mathrm{~kJ} / \mathrm{mol}$ (commercial catalyst) which is similar to what has been reported in the literature for various catalysts $[9,16]$.

Fig. 5 compares the measured and simulated development in mass and mass loss rate for 5:1 catalyst/SRM 2975 mixtures. The simulation/kinetic data are able to describe the peak conversion temperature and the associated part of the conversion/mass loss curve, but the simulation does not describe the initial gradual increase in conversion. This behaviour may originate from an initial oxidation of a more amorphous carbon layer which needs to be described by its own kinetic data [8].

\section{Conclusions}

A systematic lab-scale investigation of diesel particulate matter conversion in the presence of catalytic materials and simulated biodiesel ash species (at $10 \% \mathrm{O}_{2}$ ) has been performed. The presence of a commercial catalyst without biodiesel ash species in tight contact with the particulate matter or carbon nanopowder (5:1 wt. ratio of catalyst to soot) caused a $\sim 150^{\circ} \mathrm{C}$ decrease in peak conversion temperature (from $662 \pm 1$ and $723 \pm 1{ }^{\circ} \mathrm{C}$ to $526 \pm 19$ and $571 \pm 16{ }^{\circ} \mathrm{C}$ respectively). The lower temperature reported for catalytic DPF regeneration $\left(250-300{ }^{\circ} \mathrm{C}\right.$ in real automotive exhausts) [2] is likely due to the presence of $\mathrm{NO}_{2}-$ an aspect $\left(\mathrm{NO}_{2} /\right.$ catalyst/soot/ash interactions) that is not covered by this work. Catalytic diesel PM conversion (5:1 catalyst to diesel PM wt. ratio) benefits from the presence of biodiesel ash species such as $\mathrm{Na}_{2} \mathrm{CO}_{3}$, $\mathrm{K}_{2} \mathrm{CO}_{3}$ or $\mathrm{K}_{3} \mathrm{PO}_{4}$ - which decreased the peak conversion temperature from $526 \pm 19{ }^{\circ} \mathrm{C}$ to $\sim 400-420{ }^{\circ} \mathrm{C}$, with a limited dependence on ash concentration $\left(+20^{\circ} \mathrm{C}\right.$ for a $80 \%$ lower salt concentration). Other ash species, which may form from engine oil $\left(\mathrm{CaSO}_{4}\right.$ and $\mathrm{Ca}\left(\mathrm{H}_{2} \mathrm{PO}_{4}\right)$ or combinations of engine oil and fuel $\left(\mathrm{K}_{2} \mathrm{SO}_{4}\right)$ can have a detrimental effect on catalytic PM conversion - i.e. peak conversion temperatures of $569 \pm 6 ; \quad 699 \pm 13$ and $581 \pm 16^{\circ} \mathrm{C}$ respectively.

Kinetic parameters ( $A$ and $E_{a}$ ) obtained from Arrhenius plots showed a lower activation energy in the presence of the commercial catalyst $\left(E_{a}=91 \pm 5 \mathrm{~kJ} / \mathrm{mol}\right)$ or $\mathrm{CeO}_{2}\left(E_{a}=62 \pm 8 \mathrm{~kJ} / \mathrm{mol}\right) \mathrm{com}$ pared to pure SRM $2975\left(E_{a}=220 \pm 3 \mathrm{~kJ} / \mathrm{mol}\right)$ The obtained kinetic data was able to simulate/describe the peak conversion temperature and the associated part of the mass loss curve, but an initial gradual increase in conversion was not adequately described.

With respect to the operation of diesel particulate filters while using biodiesel as fuel, the results obtained imply that the presence of sodium or potassium as carbonates or phosphates benefit the diesel particulate matter conversion and thereby DPF regeneration. However, as diesel particulate matter is converted the ash may accumulate locally in the filter, thereby removing the required tight PM/catalyst/ash contact. Build-up of excessive levels of ash in the filter may furthermore still be detrimental to DPF regeneration performance.

\section{Acknowledgements}

This work is part of the research project, 'Renewable Energy in the transport sector using Bio-fuels as an Energy Carrier (REBECA). Financial support by the Programme Commission on Energy and Environment under the Danish Strategic Research Council is gratefully acknowledged. The authors furthermore wish to thank project chemist Henrik Christensen and Dinex A/S for their valuable input and for supplying catalytic material, post.doc Jakob Munkholt Christensen for valuable discussions and technician Lilian B. Holgersen for technical assistance.

\section{References}

1] Directive 2009/28/EC of the European parliament and of the council of 23 April 2009 on the promotion of the use of energy from renewable sources and amending and subsequently repealing Directives 2001/77/EC and 2003/30/EC.

[2] Sappok, AG., Wong, VW. Impact of biodiesel on ash emissions and lubricant properties affecting fuel economy and engine wear. DEER August 2007; MI.

[3] Castellino F, Jensen AD, Johnsson JE, Fehrmann R. Influence of reaction products of K-getter fuel additives on commercial vanadia-bassed SCR catalysts - Part I. Potassium phosphate. Appl Catal B: Environ 2009;86(3-4): 196-205.

[4] Castellino F, Jensen AD, Johnsson JE, Fehrmann R. Influence of reaction products of K-getter fuel additives on commercial vanadia-bassed SCR catalysts - Part II. Simultaneous addition of $\mathrm{KCl}, \mathrm{Ca}(\mathrm{OH})_{2}, \mathrm{H}_{3} \mathrm{PO}_{4}$ and $\mathrm{H}_{2} \mathrm{SO}_{4}$ in a hot flue gas at a SCR pilot-scale setup. Appl Catal B: Environ 2009;86(3-4): 206-15.

[5] Castellino F, Rasmussen SB, Jensen AD, Johnsson JE, Fehrmann R. Deactivation of vanadia-based commercial SCR catslysts by polyphosphoric acids. Appl Catal B: Environ 2008;83(1-2):110-22.

[6] Morcos, M., Ayyappan, P., Harris, T. Characterization of dpf ash for development of dpf regeneration control and ash cleaning requirements. SAE technical papers 2011.

[7] Sappok A, Wong V. Ash effects on diesel particulate filter pressure drop sensitivity to soot and implications for regeneration frequency and dpf control. SAE Int 2010;3(1):380-96.

[8] Liati A, Eggenschwiler PD. Characterization of particulate matter deposited in diesel particulate filters: visual and analytical approach in macro-, micro- and nano-scales. Combust Flame 2010;157(9):1658-70.

[9] Ciambelli P, Corbo P, Parrella P, Scialo M, Vaccaro S. Catalytic oxidation of soot from diesel exhaust gases. 1 . Screening of metal oxide catalysts by TG-DTGDTA analysis. Thermochim Acta 1990;162(1):83-9.

[10] Konstandopoulos AS, Lorentzou S, Pagkoura C, Ohno K, Ogyu K, Oya T. Sustained soot oxidation in catalytically coated filters. SAE Trans 2008;16(4): 508-15.

[11] Konstandopoulos AS, Papaioannou E. Update on the science and technology on diesel particulate filters. Kona Powder Part J 2008;26:36-65.

[12] Bardasz E, Mackney D, Britton N, Kleinscheck G, Olofsson K, Murray I, et al. Investigations of the interactions between lubricant-derived species and aftertreatment systems on a state-of-the-art heavy duty diesel engine. SAE Trans 2003;112(4):1821-39.

[13] Rodriguez-Fernandez J, Oliva F, Vazquez RA. Characterization of the diesel soot oxidation process through an optimized thermogravimetric method. Energy Fuels 2011;25(5):2039-48

[14] Strzelec, A., Toops, T., Daw, S., Foster, D., Rutland, C. Particulate matter oxidation kinetics: surface area dependence. CLEERS MI April 2010.

[15] Composition of diesel particulate filter ash and confirmation that fsx pneumatic cleaning process does not damage washcoats, FSX Inc. <http:// www.fsxinc.com> [accessed 25.06.11];2009.

[16] Stanmore BR, Brilhac JF, Gilot P. The oxidation of soot: a review of experiments, mechanisms and models. Carbon 2001;39(15):2247-68.

[17] Neeft JPA, Makkee M, Moulijn JA. Catalytic oxidation of carbon black - I. Activity of catalyst and classification of oxidation profiles. Fuel 1998;77(3):111-9.

[18] McKee DW. Mechanisms of the alkali metal catalysed gasification of carbon. Fuel 1983;62(2):170-5

[19] Beauboeuf, DP. Microscopy investigations of ash and particulate matter accumulation in diesel particulate filter pores, BSc thesis, Dept Mech Eng, USA: Massachusetts Institute of Technology;2010. 
[20] Neeft JPA, van Pruissen OP, Makkee M, Moulijn JA. Catalysts for the oxidation of soot from diesel exhaust gases - II. Contact between soot and catalyst under practical conditions. Appl catal B: Environ 1997;12(1):21-39.
[21] Saracco G, Specchia V. Catalytic filters for the abatement of volatile organic compounds. Chem Eng Sci 2000;55(5):897-908.

[22] Levenspiel O. Chemical Reaction Engineering. 3rd ed. John Wiley \& Sons; 1999. 